\title{
Long-term landscape changes in a subalpine spruce-fir forest in central Utah, USA
}

\author{
Jesse L. Morris ${ }^{1 *}$, R. Justin DeRose ${ }^{2}$ and Andrea R. Brunelle ${ }^{3}$
}

\begin{abstract}
Background: In Western North America, increasing wildfire and outbreaks of native bark beetles have been mediated by warming climate conditions. Bioclimatic models forecast the loss of key high elevation species throughout the region. This study uses retrospective vegetation and fire history data to reconstruct the drivers of past disturbance and environmental change. Understanding the relationship among climate, antecedent disturbances, and the legacy effects of settlement-era logging can help identify the patterns and processes that create landscapes susceptible to bark beetle epidemics.
\end{abstract}

Methods: Our analysis uses data from lake sediment cores, stand inventories, and historical records. Sediment cores were dated with radiometric techniques $\left({ }^{14} \mathrm{C}\right.$ and $\left.{ }^{210} \mathrm{~Pb} /{ }^{137} \mathrm{Cs}\right)$ and subsampled for pollen and charcoal to maximize the temporal resolution during the historical period (1800 CE to present) and to provide environmental baseline data (last 10,500 years). Pollen data for spruce were calibrated to carbon biomass (C t/ha) using standard allometric equations and a transfer function. Charcoal samples were analyzed with statistical models to facilitate peak detection and determine fire recurrence intervals.

Results: The Wasatch Plateau has been dominated by Engelmann spruce forests for the last 10,500 years, with subalpine fir becoming more prominent since 6000 years ago. This landscape has experienced a dynamic fire regime, where burning events are more frequent and of higher magnitude during the last 3000 years. Two important disturbances have impacted Engelmann spruce in the historical period: 1) high-grade logging during the late $19^{\text {th }}$ century; and (2) a high severity spruce beetle outbreak in the late $20^{\text {th }}$ century that killed $>90 \%$ of mature spruce ( $>10 \mathrm{~cm} \mathrm{dbh}$ ).

Conclusions: Our study shows that spruce-dominated forests in this region are resilient to a range of climate and disturbance regimes. Several lines of evidence suggest that $19^{\text {th }}$ century logging promoted a legacy of simplified stand structure and composition such that, when climate became favorable for accelerated beetle population growth, the result was a landscape-scale spruce beetle outbreak. The lasting impacts of settlement-era landscape history from the Wasatch Plateau, UT may be relevant for other areas of western North America and Europe where sufficient host carrying capacity is important in managing for resistance and resilience to outbreaks.

Keywords: Spruce beetle, Climate change, Dendroctonus, Engelmann spruce, Logging, Western North America, Wildfire

\footnotetext{
*Correspondence: jlmorris@uidaho.edu

'Department of Forest, Rangeland, and Fire Sciences, College of Natural

Resources, University of Idaho, Moscow, ID 83844, USA

Full list of author information is available at the end of the article
}

\section{Springer}

(c) 2015 Morris et al. Open Access This article is distributed under the terms of the Creative Commons Attribution 4.0 International License (http://creativecommons.org/licenses/by/4.0/), which permits unrestricted use, distribution, and reproduction in any medium, provided you give appropriate credit to the original author(s) and the source, provide a link to the Creative Commons license, and indicate if changes were made. 


\section{Background}

During the $21^{\text {st }}$ century, the impacts of global environmental change are projected to alter the frequency and severity of landscape disturbances, including wildfire and insect outbreaks (Raffa et al. 2008; Flannigan et al. 2009). In Western North America (WNA), fire regimes are likely to intensify in response to lengthening of fire season from diminished snowpack (Westerling et al. 2006). Warming temperatures will also promote outbreaks of native bark beetles (Curculionidae: Scolytinae) and other forest insects and pathogens, leading to additional tree mortality (Bentz et al. 2010). Individual and successive disturbances influence the capability of ecosystems to return to pre-disturbed states and can also facilitate alternative successional pathways, which can exacerbate turnover rates during periods of rapid climate transition (Turner 2010). Conifer-dominated forests in WNA face an uncertain future from concomitant climate warming and disturbance regime intensification (Rehfeldt et al. 2006; Westerling et al. 2006). Some bioclimatic models predict that warming temperatures will drive Engelmann spruce-subalpine fir forests (Picea engelmannii-Abies lasiocarpa) to be replaced by grasslands (Poaceae) in the coming century (Notaro et al. 2012). Recent studies suggest that unusually severe disturbances can promote transitions of forested landscapes to grasslands (e.g. Savage and Mast 2005; Odion et al. 2010).

Retrospective ecological records, such as those derived from lake sediments, are essential to understand baseline vegetation conditions and past disturbance regime variability. Lake sediment records span decadal to millennial timescales, and these data help to assess recent and future disturbance impacts, ecosystem services, biodiversity, and changes in vegetation composition relative to baseline conditions (Willis and Birks 2006; Willis et al. 2010; Dawson et al. 2011; Jeffers et al. 2015). The dynamics of wildfire disturbances can be reconstructed reasonably well in paleoecological studies through the analysis of charcoal preserved in sedimentary records (Whitlock et al. 2010), including information about the recurrence, severity, and fuel sources of past fire events (Enache and Cumming 2007; Calder et al. 2015). The reconstruction of bark beetle disturbances centers on the host-specific requirements of the disturbance agent, and abrupt, relative changes in vegetation composition (i.e. host to non-host) that can be detected in pollen assemblages (Anderson et al. 2010; Morris and Brunelle 2012).

In this paper we use pollen and charcoal proxies from two lake sediment cores, forest demographic data, and historical records to understand the dynamics and interactions of natural (beetles, wildfire) and anthropogenic (logging) disturbances on a subalpine spruce-fir forest in central Utah. Our study aims to use retrospective data to understand the interactions of long-term climate change and disturbances by addressing the following three questions: 1) How did the dynamics of a spruce-fir forest respond to climate change and disturbance over the Holocene? 2) How does understanding human modifications to a spruce-fir landscapes help inform our understanding of a recent, high-severity spruce beetle outbreak? and 3) What do reconstructions of host-specific biomass (C $\mathrm{t} / \mathrm{ha}$ ) reveal about the antecedent conditions in a spruce-fir ecosystem that supported a high-severity outbreak?

\section{Methods \\ Study area}

The Wasatch Plateau is a steeply sloped, fault-block landform encompassing an area of $2477 \mathrm{~km}^{2}$, mostly situated above $3000 \mathrm{~m}$ in central Utah, USA. Prevailing climate of this landform is generally continental, with a complex bimodal precipitation regime shaped by heterogeneous topography and multiple moisture delivery pathways (Mock 1996). The Wasatch Plateau was used for timber harvesting and livestock grazing during the $19^{\text {th }}$ century settlement-era (Hall 2001). By the early $20^{\text {th }}$ century, the results of early land use practices resulted in severely denuded landscapes and the Wasatch Plateau was considered among the most detrimentally impacted rangelands in WNA (Hall 2001). While early commercial logging practices tended to favor harvesting of largediameter class sizes of straight-grained species like ponderosa pine (Pinus ponderosa) and Douglas-fir (Pseudotsuga menziesii), the steep escarpments of the Wasatch Plateau has little mid-montane habitat to support prized commercial species and therefore Engelmann spruce was often selected (Ellison 1954; Hall 2001; Gill 2007). Also, an important associate in many spruce-fir forests of the Northern and Central Rocky Mountains, lodgepole pine (Pinus contorta), is absent from the Utah 'Plateaus' (i.e., Wasatch Plateau) that characterize the western flank of the Colorado Plateau (Critchfield and Little, 1966). Like other merchantable species, spruce of larger size classes were harvested first (i.e., high-grading), resulting in homogenized forest composition dominated by the relatively short-lived subalpine fir and understory spruce (Arno and Hammerly 1984; Hall 2001). By the late $20^{\text {th }}$ century, the subalpine forest zone was composed of dense stands of Engelmann spruce that released (or regenerated) during the settlement-era logging.

In the late-1980s endemic populations of spruce beetle (Dendroctonus rufipennis) established in the Nine Mile Creek drainage of the Wasatch Plateau following a slope failure event (Dymerski et al. 2001). Spruce beetle rapidly increased to outbreak levels in response to the warm temperatures of the 1990s (Hebertson and Jenkins 2008), causing $>90 \%$ mortality in mature Engelmann spruce (> $10 \mathrm{~cm}$ in diameter) across $\sim 75,000$ ha of 
subalpine forest (Dymerski et al. 2001). The epidemic persisted until mature hosts were exhausted, resulting in a collapse of the spruce beetle population and outbreak cessation. To investigate the vegetation history of the Wasatch Plateau we collected sediment cores from two subalpine lakes that experienced the high severity outbreak during the 1990s. Blue Lake (39 $3^{\circ} 20.33^{\prime \prime} \mathrm{N}, 111^{\circ}$ $\left.30^{\prime} 17.43^{\prime \prime} \mathrm{W}\right)$ and Emerald Lake $\left(39^{\circ} 4{ }^{\prime} 26.72^{\prime \prime} \mathrm{N}, 111^{\circ}\right.$ $29^{\prime} 50.964 " \mathrm{~W}$ ) (Fig. 1) were selected because they matched four criterion: (1) high-severity damage from spruce beetle ( $>90 \%$ spruce mortality) in surrounding forest; (2) limited surface water inflow/outflow; (3) absence of constructed dams and/or berms; and (4) no known wildfire events during the historical period.

\section{Age-depth models}

Chronology for the upper $24 \mathrm{~cm}$ of sediment collected from Emerald Lake and Blue Lake was established through the analysis of the radiometric isotopes of lead $\left({ }^{210} \mathrm{~Pb}\right)$ and cesium $\left({ }^{137} \mathrm{Cs}\right)$ (Fig. 2; Table 1). In preparation for ${ }^{210} \mathrm{~Pb} /{ }^{137} \mathrm{Cs}$ analysis, 12 samples representing 2-cm increments of the Emerald Lake core were weighed and dried in a muffle furnace at $100{ }^{\circ} \mathrm{C}$ to remove water content. For Blue Lake, subsamples were prepared for each contiguous $\mathrm{cm}$ for the upper $24 \mathrm{~cm}$. Next, dehydrated samples were submitted for analysis to the USGS Laboratory in Denver, CO. The 1963 CE peak in ${ }^{137} \mathrm{Cs}$ is derived from aboveground nuclear weapons testing and this distinct peak is instructive for interpreting the ${ }^{210} \mathrm{~Pb}$ profile (Morris and Brunelle 2012). The uppermost $\mathrm{cm}$ (i.e. core top) was assigned to the year of core retrieval and used in age model construction, which corresponds to $2007 \mathrm{CE}$ (common era) for Emerald Lake and 2005 CE for Blue Lake.

Accelerator mass spectrometry (AMS) ${ }^{14} \mathrm{C}$ dates were obtained from plant macrofossils isolated during charcoal analysis (see below) (Fig. 2; Table 1). For Emerald Lake, eight macrofossil samples were analyzed at the Center for Applied Isotope Studies (CAIS) at the University of Georgia USA. For Blue Lake, two macrofossil samples were analyzed at Beta Analytical, Inc. located in Miami, Florida USA (Morris et al. 2010). The INTCAL09 calibration set (Calib 7.1) was used to convert ${ }^{14} \mathrm{C}$ ages to calendar years before present (years hereinafter) (Reimer et al. 2013). Due to a reversal, one AMS date from Emerald Lake was rejected (Table 2). Therefore, seven dates were used to build the Emerald Lake age-depth model using CLAM script in the R software package (Blaauw 2010). Age-depth relations for Blue Lake were calculated using a linear interpolation.

\section{Pollen sampling and analysis}

For the high temporal resolution necessary to track the land use and outbreak history, we analyzed every

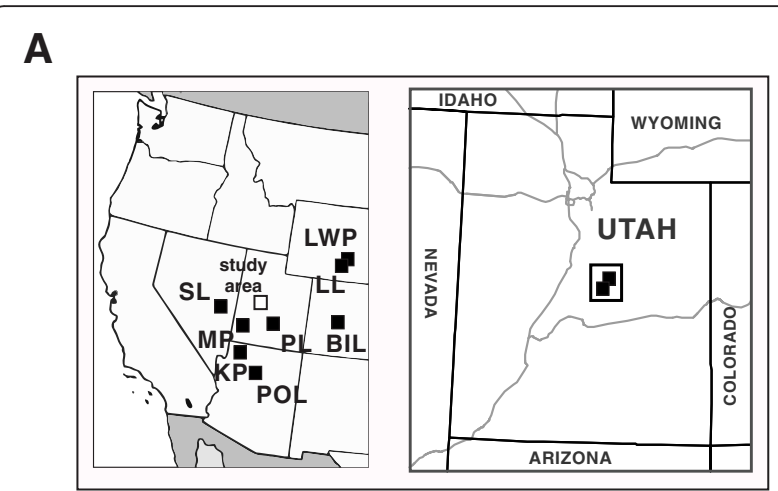

B

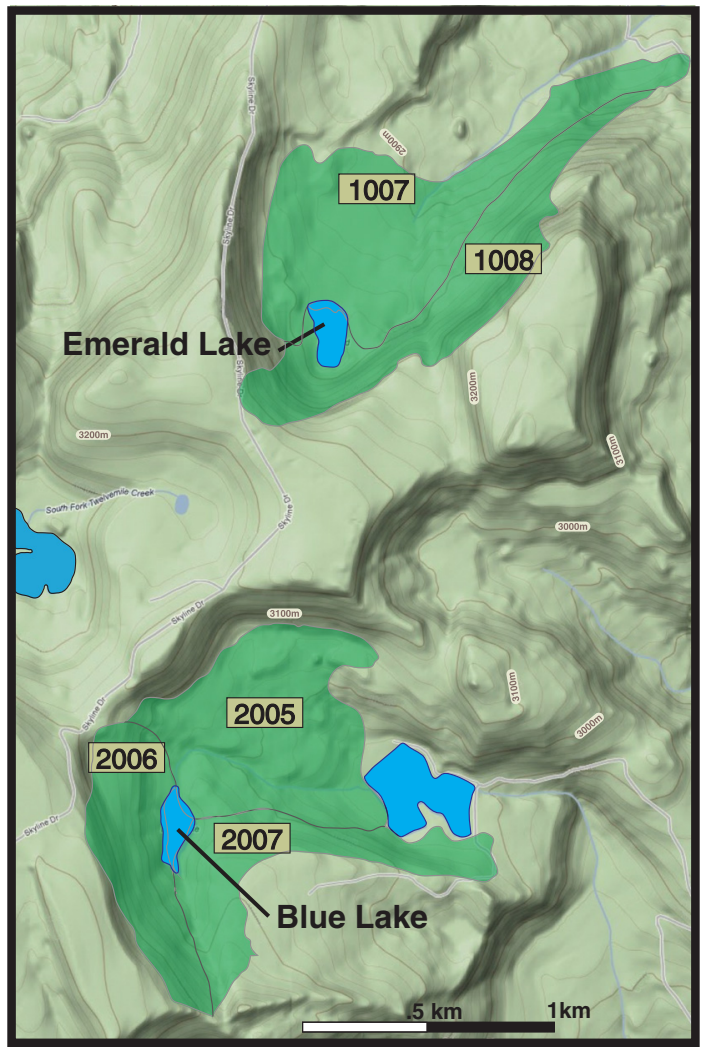

Fig. 1 Map depicting the study area and proximal sites discussed here: Bison Lake (BIL; Anderson 2011), Kaibab Plateau (KP; Weng and Jackson 1999; Little Windy Hill Pond (LWHP; Minckley et al. 2012), Long Lake (LL; Carter et al. 2013); Markagunt Plateau (MP; Anderson et al. 1999; Morris et al. 2013a), Purple Lake (PL; Morris et al. 2013b), Potato Lake (POL; Anderson 1993), and Stella Lake (SL; Reinemann et al. 2009). Location and forest inventory plots within the catchments of Emerald Lake (1007 and 1008) and Blue Lake (2005, 2006, and 2007) are also depicted. See Table 2 for inventory summaries

contiguous $\mathrm{cm}$ for Emerald Lake and Blue Lake for the uppermost sediments $(24 \mathrm{~cm})$. For Emerald Lake sediments below $24 \mathrm{~cm}$, pollen was analyzed at $4 \mathrm{~cm}$ ( 100 year) intervals. At Blue Lake they were analyzed at $8 \mathrm{~cm}(\sim 250$ year $)$ intervals. Pollen analysis followed standard acid digestion procedures (Fægri 


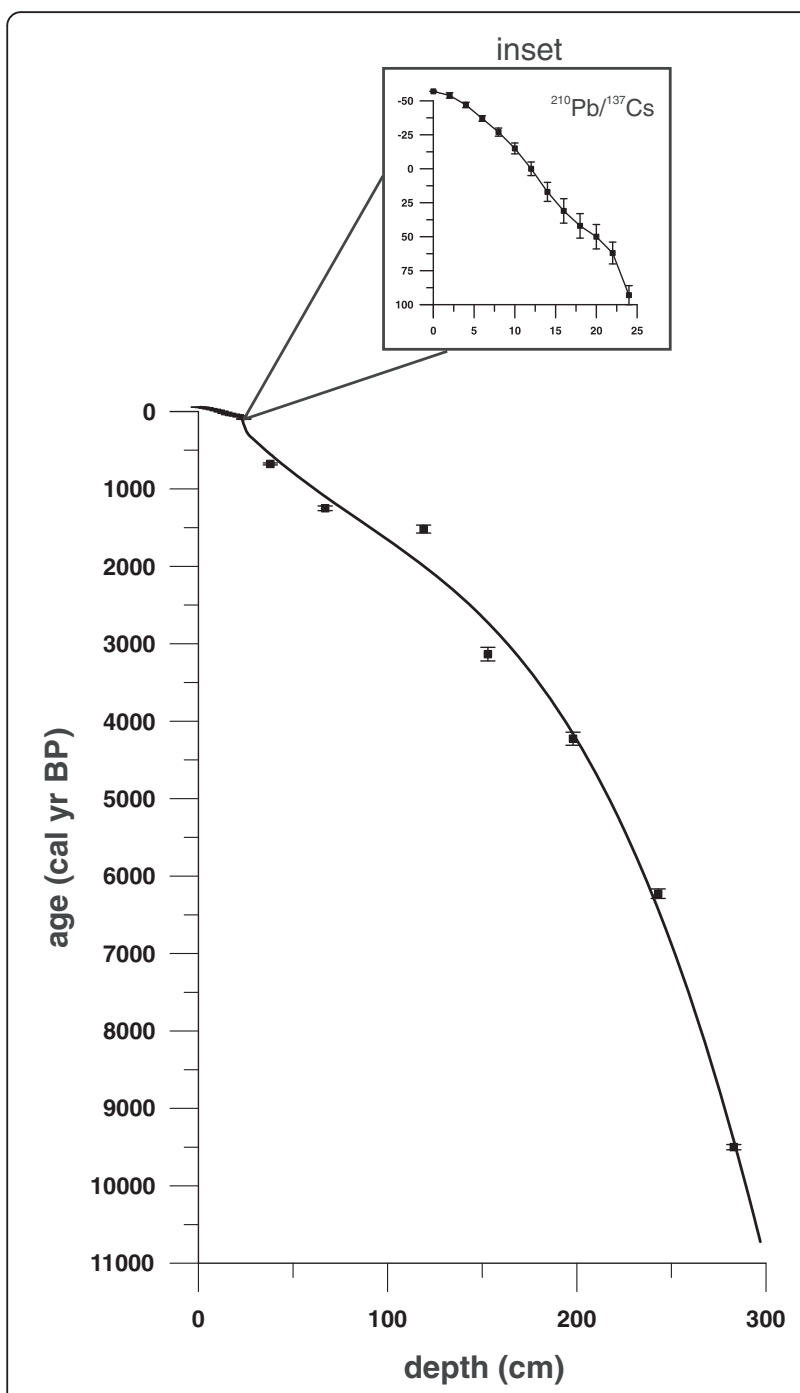

Fig. 2 Summary plot of age-depth relationships for Emerald Lake, Utah based on twelve ${ }^{210} \mathrm{~Pb} /{ }^{137} \mathrm{PC}$ dates (inset) and seven ${ }^{14} \mathrm{C}$ dates. Age-depth model was created using CLAM software (Blaauw 2010) in R

et al. 1989), and known concentrations of exotic club moss spores (i.e. Lycopodium) were introduced to each sample to establish pollen accumulation rates (PAR) (grains $/ \mathrm{cm}^{2} /$ year). PAR were calculated by multiplying raw pollen counts by sedimentation rate $\left(\mathrm{cm}^{2} /\right.$ year) (Giesecke et al. 2010). Pollen residues were classified and tabulated using light microscopy at $500 \times$ until a minimum of 300 terrestrial grains were counted. Pollen identification was assisted by relevant keys and literature (e.g. Kapp et al. 2000). The ratio of spruce to fir pollen was calculated as (a$\mathrm{b}) /(\mathrm{a}+\mathrm{b})$, where $\mathrm{a}=$ spruce and $\mathrm{b}=$ fir. We assume that spruce and fir pollen types, which are generally not diagnostic to species-level assignment, are reflective of Engelmann spruce and subalpine fir in this environmental setting.

\section{Charcoal sampling and analysis}

For Emerald Lake, subsamples for charcoal analysis $\left(5 \mathrm{~cm}^{3}\right)$ were analyzed for each contiguous $\mathrm{cm}$ and were prepared by standard conventions (Whitlock and Millspaugh 1996). Sediments were screened through $125-\mu \mathrm{m}$ and $250-\mu \mathrm{m}$ nested sieves and tabulated using light microscopy at $40 \times$ magnification. Fraction sizes $>250-\mu \mathrm{m}$ do not travel far from their source and therefore represent catchment-scale fire history (Clark 1988; Gardner and Whitlock 2001). Charcoal counts were converted to concentration (particles $/ \mathrm{cm}^{3}$ ) and then influx (particles $/ \mathrm{cm}^{2} /$ year). We minimized variations in the record from changes in sediment deposition rates by binning concentrations using the median sediment deposition time (25 years), which were converted to charcoal accumulation rates (CHAR, particles $/ \mathrm{cm}^{2} /$ year) and then decomposed into background (BCHAR) and peak components (Higuera et al. 2009). By decomposing CHAR, the low frequency variation is reflected in BCHAR while high frequency deviations (i.e. positive) from BCHAR represent charcoal delivery originating from a significant fire episode. To determine peaks above BCHAR, we first applied a Lowess smoother robust to outliers, within a 500-year window width and then subtracted background values for each time interval from the total CHAR accumulation (for each interval) (Higuera et al. 2010). The peak accumulations in charcoal (i.e., intervals with CHAR values above BCHAR) were tested for significance using a Gaussian distribution ( $>95$ th percentile). We applied this procedure to every 500-year overlapping portion of the record, thereby producing a unique threshold for each subsample. Once all peaks were identified using this criterion, we screened our results to eliminate peaks that might have resulted from statistically insignificant variations in CHAR (Gavin et al. 2006). Specifically, if the maximum CHAR values corresponding to a detected peak had a $>5 \%$ chance of coming from the same Poisson-distributed population as the minimum charcoal count of the antecedent 25 -years period, then we rejected the peak (Higuera et al. 2010).

\section{Forest inventory data}

The USFS collected district-specific stand inventories in 1994 CE during the spruce beetle outbreak in the Emerald Lake and Blue Lake catchments (Fig. 1, Table 2). At each plot individual trees were noted for species and status (live or dead). When dead trees were encountered, the cause of death noted (e.g., spruce beetle). For each tree on the plot, height and diameter at breast height ( $\mathrm{dbh}$ ) were recorded and increment cores were collected for a subset of the tallest trees to determine stand age and site potential productivity (sensu Alexander 1967). We calculated total aboveground biomass $(\mathrm{C} / \mathrm{kg})$ for each tree using 
Table 1 Summary of age-depth relationships for Emerald Lake, Utah

\begin{tabular}{|c|c|c|c|c|c|c|c|c|}
\hline $\begin{array}{l}\text { Depth } \\
(\mathrm{m})^{\mathrm{a}}\end{array}$ & $\begin{array}{l}\text { Core } \\
\text { ID }\end{array}$ & $\begin{array}{l}{ }^{14} \mathrm{C} \text { Age } \pm \\
1 \sigma^{\mathrm{b}}\end{array}$ & $\begin{array}{l}2 \sigma \text { age range } \\
(\text { cal yr BP })^{c}\end{array}$ & $\begin{array}{l}\text { Relative area under } \\
\text { distribution }\end{array}$ & 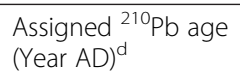 & $\begin{array}{l}\text { Assigned age } \\
\text { (cal yr BP) }\end{array}$ & $\begin{array}{l}\text { Material } \\
\text { dated }\end{array}$ & $\begin{array}{l}\text { Lab ID } \\
\text { Number }\end{array}$ \\
\hline 0.00 & EL07A & & & & $2007 \pm 0^{\mathrm{e}}$ & -57 & core top & $n / a$ \\
\hline 0.02 & EL07A & & & & $2004 \pm 2$ & -54 & gyttja & EL07A0102 \\
\hline 0.04 & EL07A & & & & $1997 \pm 2$ & -47 & gyttja & EL07A0304 \\
\hline 0.06 & EL07A & & & & $1987 \pm 2$ & -37 & gyttja & EL07A0506 \\
\hline 0.08 & EL07A & & & & $1977 \pm 3$ & -27 & gyttja & EL07A0708 \\
\hline 0.10 & EL07A & & & & $1965 \pm 4$ & -15 & gyttja & EL07A0910 \\
\hline 0.12 & EL07A & & & & $1950 \pm 5$ & 0 & gyttja & EL07A 1112 \\
\hline 0.14 & EL07A & & & & $1933 \pm 5$ & 17 & gyttja & EL07A1314 \\
\hline 0.16 & EL07A & & & & $1919 \pm 9$ & 31 & gyttja & EL07A1516 \\
\hline 0.18 & EL07A & & & & $1908 \pm 9$ & 43 & gyttja & EL07A1718 \\
\hline 0.20 & EL07A & & & & $1900 \pm 9$ & 50 & gyttja & EL07A1920 \\
\hline 0.22 & EL07A & & & & $1888 \pm 8$ & 62 & gyttja & EL07A2324 \\
\hline 0.24 & EL07A & & & & $1857 \pm 7$ & 93 & gyttja & EL07A2123 \\
\hline 0.38 & EL07A & $735 \pm 15$ & $666-688$ & 1.000 & & 677 & macro & 4781 \\
\hline 0.67 & EL07A & $1280 \pm 15$ & $1223-1275$ & 0.594 & & 1249 & macro & 4783 \\
\hline $0.81^{f}$ & EL07C & $2451 \pm 27$ & $2362-2542$ & 0.547 & & 2452 & macro & 4785 \\
\hline 1.20 & ELO7C & $1617 \pm 26$ & $1474-1562$ & 0.620 & & 1518 & macro & 4787 \\
\hline 1.54 & EL07C & $2958 \pm 24$ & $3057-3209$ & 0.973 & & 3133 & macro & 4789 \\
\hline 1.99 & EL07C & $3843 \pm 27$ & $4153-4300$ & 0.787 & & 4227 & macro & 4791 \\
\hline 2.44 & ELO7C & $5381 \pm 28$ & $6174-6281$ & 0.804 & & 6228 & macro & 4793 \\
\hline 2.84 & EL07C & $8483 \pm 26$ & $9471-9530$ & 1.000 & & 9501 & macro & 4795 \\
\hline
\end{tabular}

adepth below the sediment-water interface

${ }^{\mathrm{b}} \mathrm{AMS}{ }^{14} \mathrm{C}$ age determinations from Center for Applied Isotope Studies (CAIS) at the University of Georgia

${ }^{\mathrm{c} 14} \mathrm{C}$ ages calibrated to calendar years before present (Cal yr BP) with INTCAL09 in Calib 7.0 (Reimer et al. 2013)

${ }^{\mathrm{d} 210} \mathrm{~Pb} /{ }^{137} \mathrm{Cs}$ ages from USGS Denver determined by Constant Rate of Supply (Appleby et al., 1979) adjusted for 1963 AD ${ }^{137} \mathrm{Cs}$ peak

${ }^{\mathrm{e}}$ Core top sample assigned to year of core retrieval

fdate rejected due to reversal

standard allometric equations from individual tree height and diameter (Ter-Mikaelian and Korzukhin 1997). Tree-level carbon biomass estimates were summed for total and species-specific estimates at the plot-level ( $\mathrm{Ct} / \mathrm{ha}$ ) (Table 2). The plots were then averaged for a catchment-level estimate of Engelmann

Table 2 Summary of stand attributes for Wasatch Plateau, Utah

\begin{tabular}{lll}
\hline & $\begin{array}{l}\text { Blue } \\
\text { Lake }\end{array}$ & $\begin{array}{l}\text { Emerald } \\
\text { Lake }\end{array}$ \\
\hline Watershed size $\left(\mathrm{ha}^{-1}\right.$ ) & 132 & 116 \\
Number plots (stocked) & 34 & 26 \\
Age of dominant Picea & $117(8)$ & $140(11)$ \\
Total basal area $\mathrm{m}^{2} \mathrm{ha}^{-1}$ (se) & $43.9(6.8)$ & $24.7(4.9)$ \\
Picea basal area $\mathrm{m}^{2} \mathrm{ha}^{-1}$ (se) & $36.5(6.4)$ & $20.5(4.5)$ \\
Quadratic mean diameter of Picea engelmannii > & $43.5(3.5)$ & $33.4(4.4)$ \\
25.4 cm (se) & & \\
Trees per hectare > 12.7 cm (se) & $513(92)$ & $501(119)$ \\
Picea engelmannii biomass tonnes/ha (se) & 44.5(8.1) & $29.1(6.8)$ \\
\hline
\end{tabular}

${ }^{1}$ Biomass value used for transfer function in Fig. 5 spruce biomass ( $\mathrm{C} \mathrm{t} / \mathrm{ha})$, which was then calibrated to PAR using a transfer function (Seppä et al. 2009). This method provides a long-term reconstruction of spruce biomass ( $\mathrm{C} \mathrm{t} / \mathrm{ha}$ ), as a proxy for Engelmann spruce stand conditions, in the Emerald Lake and Blue Lake catchments.

\section{Results}

\section{Baseline environmental conditions}

The pollen-based vegetation reconstruction from the Emerald Lake catchment indicated that Engelmann spruce (15-20\%) has been dominant over the last 10,500 years (Fig. 3). Subalpine fir became prevalent (7-10\%) after $\sim 6000$ years ago while pine fluctuated (25 to $11 \%$ ) from 10,500 years ago to $\sim 6000$ years ago, before rebounding to higher values $(25 \%)$ after $\sim 3000$ years ago. Throughout the record, the pollen of sagebrush (Artemisia spp.) and asters (Asteraceae spp.) were present, consistently ranging between 15-20\% and 4-8 \%, respectively. Meadow-rue (Thalictrum spp.), cattail (Typha spp.), sedges (Cyperaceae), and willows (Salix spp.) occurred in greater abundance 
during the early record ( $~ 9000$ years ago) and then decreased towards modern. Grass pollen was complacent throughout the Emerald Lake record, ranging between 4 and $10 \%$.

From charcoal, the Emerald Lake record suggests that fire became progressively more prevalent and of higher severity from the early record until modern (Fig. 4). The mean fire return interval (MFRI) during the early record (6000 to 9000 years ago) ranged between 300 and 350 years between events. The MFRI increased to 150 200 years beginning at $\sim 3000$ years. As MFRI increased, peak magnitudes also increased (pieces $/ \mathrm{cm}^{2} /$ year) and accordingly, the BCHAR trajectory rose over the course of the record by an order of magnitude (0.02 to 0.2 pieces $/ \mathrm{cm}^{2} /$ year). A conspicuous departure from the generally increasing trend occurred at around 1000 years ago, where BCHAR declines abruptly $\left(<0.1\right.$ pieces $/ \mathrm{cm}^{2} /$ year), before resuming an increasing trajectory.

\section{Historical era}

Over the last 200 years (since $1800 \mathrm{CE}$ ), forest composition at Emerald Lake and Blue Lake were
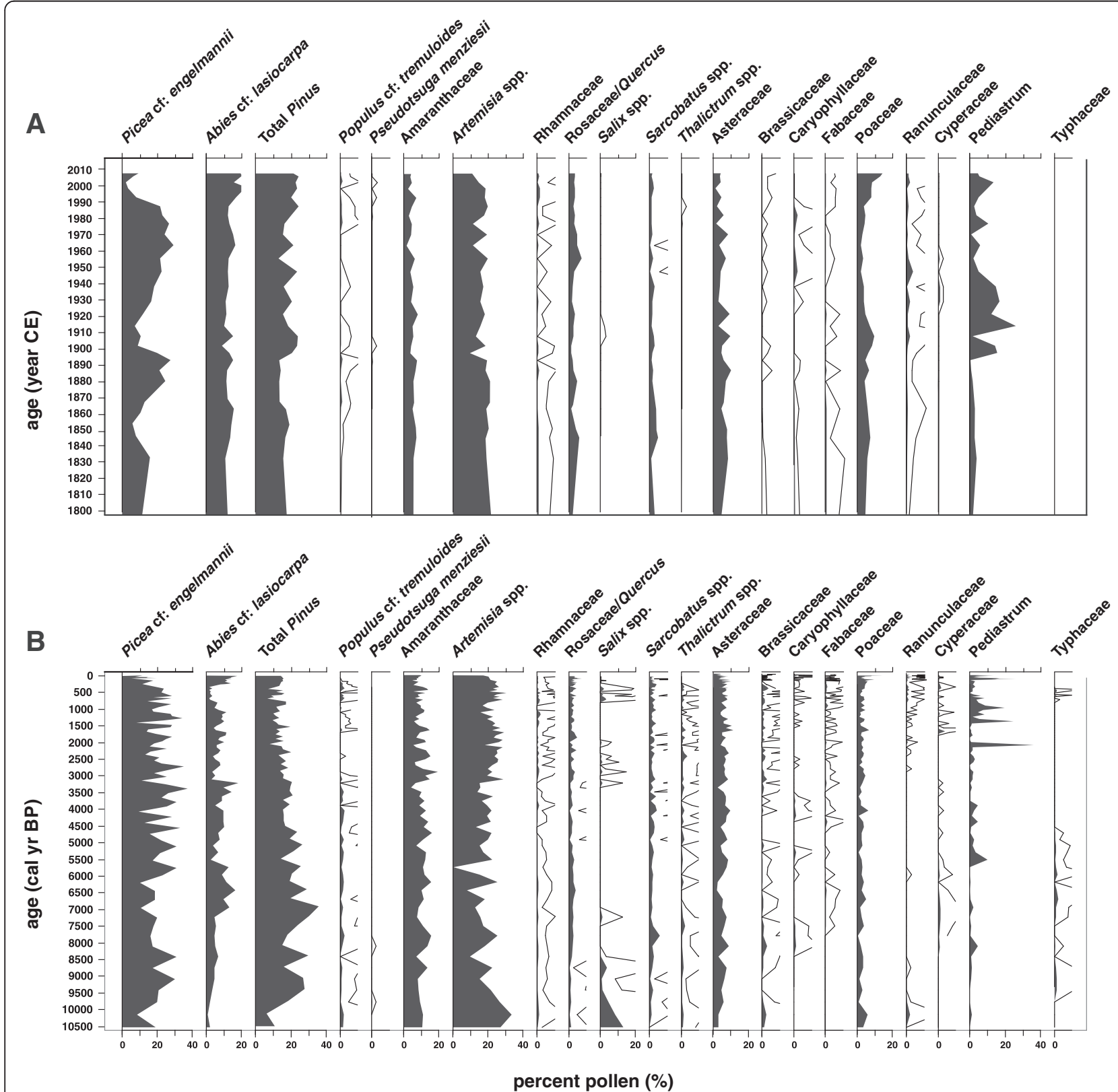

Fig. 3 Pollen diagram portraying vegetation change at Emerald Lake. Panel (a) depicts the historical period (1800 CE to present) and panel (b) shows the Holocene $(10,500$ years before present) 


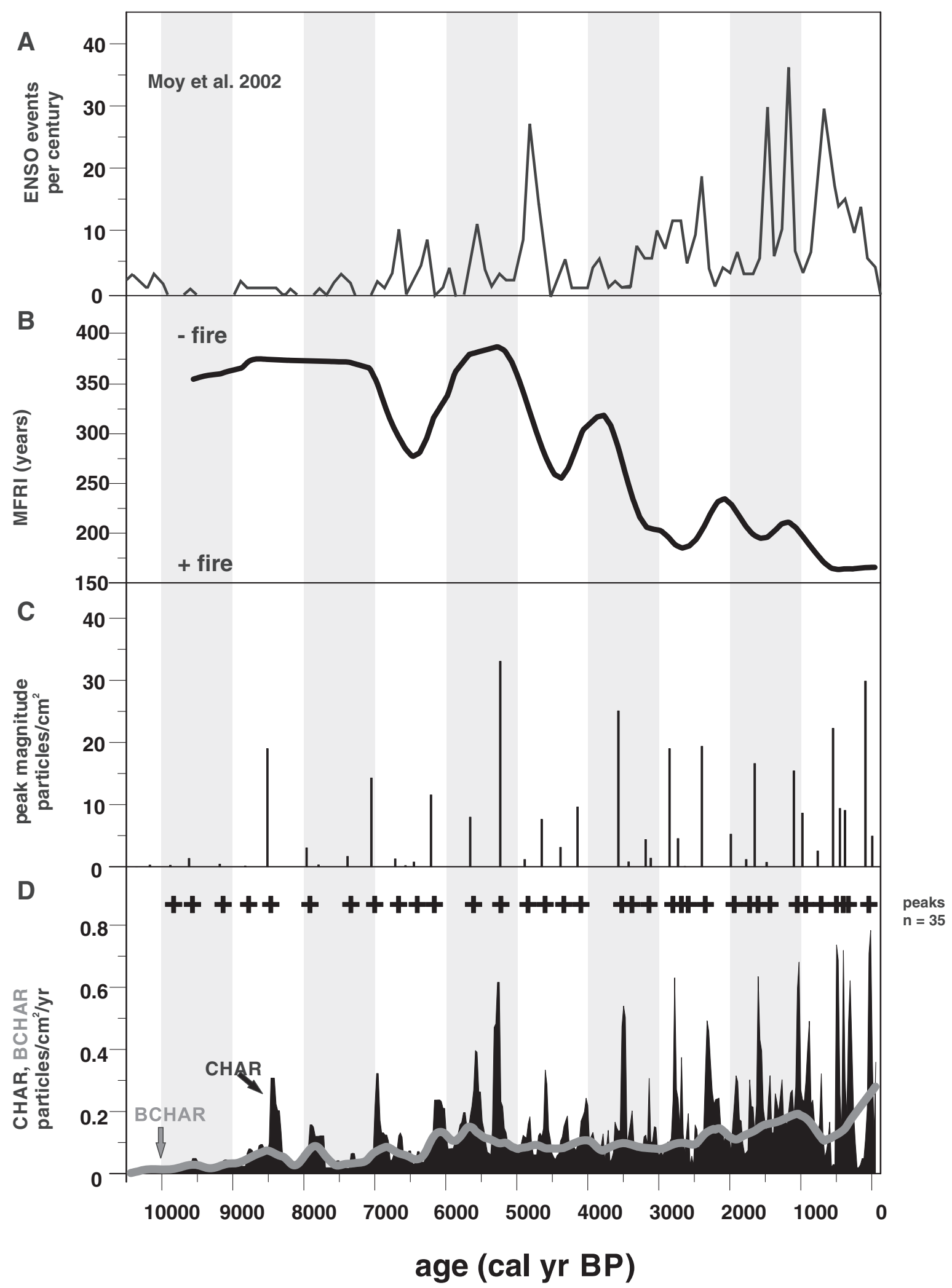

Fig. 4 Line plots showing the charcoal-based fire reconstruction for Emerald Lake. Panel (a) presents reconstructed ENSO activity (Moy et al. 2002), panel (b) depicts the fire return intervals (time since fire), panel (c) provides histograms of peak magnitude, and panel (d) shows charcoal accumulation rates (CHAR) in black silhouette plot, background charcoal (BCHAR) in gray line plot, and peak events (+). Charcoal data were analyzed using the CharAnalysis software package (Higuera et al., 2009) 
compositionally similar with spruce-fir ratios averaging $\sim 0.25$ and spruce biomass ranging between 10 and $30 \mathrm{t} / \mathrm{ha}$ for non-outbreak periods (Fig. 5). For this time period spruce biomass was well below the immediate pre-outbreak level (1950-1985 CE). Conspicuous and abrupt declines in spruce biomass at ca. $1850 \mathrm{CE}$ were likely from logging. Similarly, rapid reductions in biomass and spruce-fir ratios characterized the recent spruce beetle outbreak in both catchments. Concurrent reductions in the spruce-fir ratios corroborate a rapid shift from spruce to fir dominance at both Blue Lake and Emerald Lake. Box plots provide evidence that spruce biomass has generally been much lower relative to modern at Emerald Lake over the last 10,500 years, while at Blue Lake was more uniform during the last 5000 years (Fig. 5).

\section{Discussion}

Long-term vegetation and disturbance histories, such as those produced from sediment cores, are useful for characterizing recent events in the context of longer term dynamics. We use pollen and charcoal from two lake sediment cores, Emerald Lake and Blue Lake, along with forest demographic data and historical records to understand the dynamics and potential interactions of natural (beetles, wildfire) and anthropogenic (logging) disturbances over the Holocene, but with particular focus on the historical era. The longer-term data helped establish the precedence for spruce-fir forest and fire dynamics in the study area. Incorporating the historical narrative improved our understanding of possible anthropogenic influences on simplified forest composition, which ultimately contributed to the landscape-scale spruce beetle outbreak. The calibrated biomass transfer function represents another line of evidence that aided in teasing apart natural from anthropogenic causes of forest composition shifts in this study, and might be helpful in other regions. Finally, our results help to temper recent model-based claims that the subalpine spruce-fir forests of central Utah are particularly vulnerable to intensifying disturbance regimes and warming temperatures (Rehfeldt et al. 2006; Notaro et al. 2012).

\section{Baseline environmental context}

By focusing on the dynamics of spruce-fir systems over the Holocene, our study raises the question, how does long-term environmental data provide context for the resilience of spruce-fir forests to climate change and disturbance? The Emerald Lake record indicates that for the last 6000 years, this catchment has been dominated by forests of Engelmann spruce and subalpine fir, including common understory taxa, such as sagebrush and grass, that are compositionally similar to modern pollen representations of subalpine vegetation communities (Anderson et al. 1999; Morris et al. 2013a). In general, the vegetation community is essentially a classic WNA spruce-fir forest, which feature dense spruce-fir stands

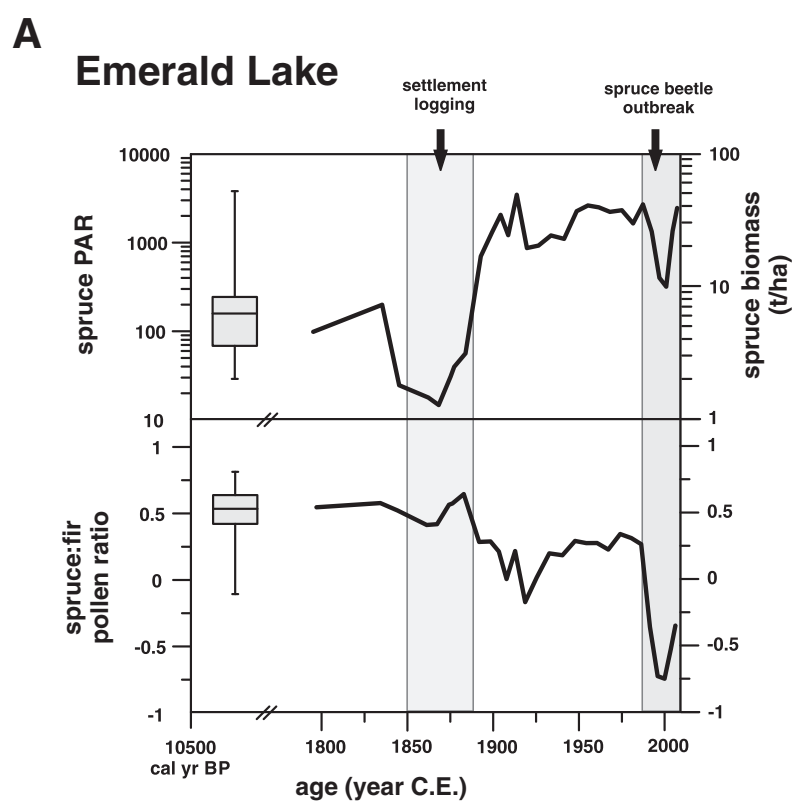

B

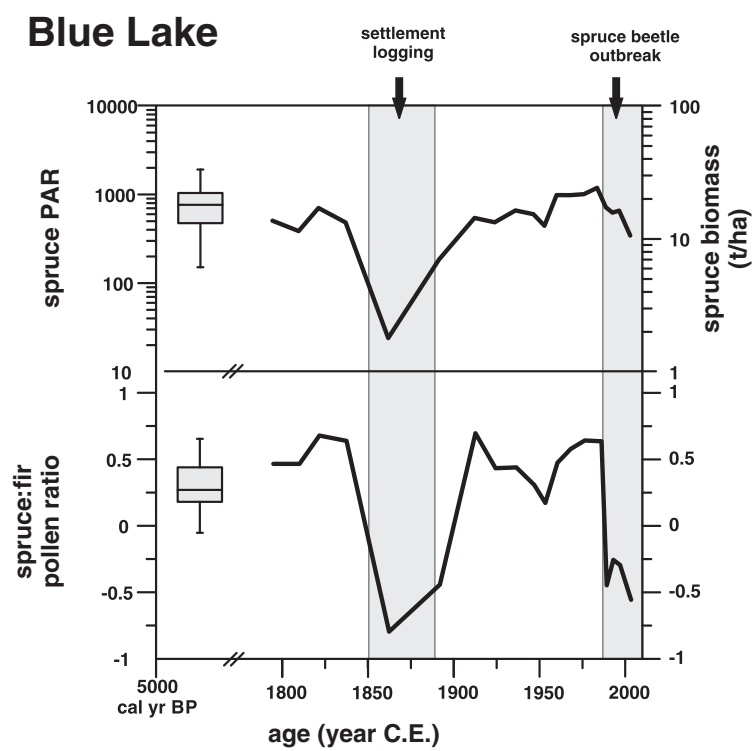

Fig. 5 Line and box plots for reconstructed Engelmann spruce pollen accumulation rates (PAR) calibrated to carbon biomass (t/ha) at Emerald Lake (panel a) and Blue Lake (panel b). Lower plots shows the ratio of spruce to fir, which is indicative of disturbances that preferentially cause spruce mortality. The shaded boxes highlight periods of documented disturbances that favored spruce mortality, such as settlement-era logging and a spruce beetle outbreak. Box plots indicate the range of variability recorded over the length of the sediment records, 10,500 cal yr BP for Emerald Lake and $5000 \mathrm{cal}$ yr BP for Blue Lake, to facilitate comparison with the historical range of variability (post-1800 CE) 
interspersed with meadows of grass, sagebrush, and other subalpine meadow taxa (Peet 1981). Over longer temporal scales, encroachment of extra-local species is improbable in our study region due to the vast expanses of low-elevation sagebrush steppe, effectively creating 'sky islands' of conifers that are common throughout WNA (e.g., O'Connor et al. 2014). Therefore, prior to anthropogenic modification, immigration of extra-local taxa to colonize new and/or vacant niches created by climate change and/or disturbance would be unlikely.

The Emerald Lake fire history indicates that MFRI ranged between 300 and 350 years between 3000 and 10,500 years ago, and after 3000 years ago, the MFRI decreased to $150-200$ years (i.e. fire became more frequent towards modern). Intensifying fire regimes over the last 3000 years contrasts other high-resolution fire histories from sites located south of the Wasatch Plateau. Purple Lake (Fig. 1) occurs at a similar elevation to Emerald Lake (3200 $\mathrm{m}$ asl), and the $\sim 9500$ year record there indicates a decreasing trajectory of fire activity during the last 3000 years (Morris et al. 2013b). Where the Emerald Lake fire history indicates a stepwise increase in charcoal accumulation beginning around 3000 years ago, the Purple Lake fire history shows a transition to essentially no fire from 3000 years ago until $1850 \mathrm{CE}$ when European settlers arrives in the region. Morris et al. (2013b) suggest that declining fire activity at Purple Lake in last 3000 years is due to increasing winter snowpack in response to increasing frequency and intensity of El NiñoSouthern Oscillation (ENSO) (Fig. 4a, see also Anderson 2011) that is known to be an important control on wildfire in central Utah (Schoennagel et al. 2005). The contrasting charcoal records from Emerald Lake and Purple Lake could be explained by placing the Wasatch Plateau into the northern (and Purple Lake in the southern) realm(s) of influence of the ENSO dipole where the boundary has historically occurred between 40 and $42^{\circ}$ $\mathrm{N}$ latitude (Wise 2010). The increasing charcoal stratigraphy at Emerald Lake, which occurs at $\sim 41^{\circ} \mathrm{N}$, resembles the fire history of lake records occurring farther north of the Wasatch Plateau, such as Little Windy Hill Pond and Long Lake (Fig. 1) (Minckley et al. 2012; Carter et al. 2013). Interestingly, both Little Windy Hill Pond and Long Lake are located in the Central Rocky Mountains in lodgepole pine forests, which is a subalpine plant community absent from the Wasatch Plateau and elsewhere on the western Colorado Plateau.

The pollen record from Emerald Lake and other high elevation lakes in the region, such as Purple Lake and Morris Pond (Morris et al. 2013a, b), together suggest that Engelmann spruce was resilient to a range of climate and fire regimes during the last 9500 years, which provides context for interpreting forecasts of bioclimatic models (Notaro et al. 2012). Paleoenvironmental reconstructions from mid-elevation forest sites in interior WNA suggest (Fig. 1) that Engelmann spruce became extinct, or locally rare, during warm intervals between 4000 and 6000 years ago (Anderson 1993; Anderson et al. 1999; Weng and Jackson 1999). However, the vegetation records from Emerald Lake and other sites (Morris et al. 2013a, b) indicate that Engelmann spruce was unaffected at high elevations. If current warming trends continue unabated and surpass thermal conditions experienced regionally in the last $\sim 10,000$ years, it is conceivable that some spruce habitat could be lost, potentially hastened by severe disturbance (e.g. Savage and Mast 2005; Odion et al. 2010).

\section{Historical era}

Our study seeks results improved our understanding of how human modifications to spruce-fir landscapes simplified species composition, an important antecedent condition for high-severity spruce beetle outbreaks. On the Wasatch Plateau, pollen records from Emerald Lake and Blue Lake clearly recorded the impacts of $19^{\text {th }}$ century spruce harvesting (Fig. 5). At both sites spruce biomass plummets coincident with regional settlement during the mid- $19^{\text {th }}$ century, decreasing by $95 \%$ at Blue Lake and $88 \%$ at Emerald Lake. At Emerald Lake the spruce:fir pollen ratio suggests that some spruce remained on the landscape, likely smaller class sizes. In general, the settlement logging event simplified stand composition by removing primarily spruce, which was favored due to its larger size, superior wood quality, and resistance to heart rot in comparison to fir (Blanchette 1982), which is supported by the age class structure of the inventory data (Table 2). The mean dbh age of spruce from the 1994 USFS stand survey for both lakes (Blue Lake $\bar{x}$ age $=117 \pm 8$ or ca. 1877 , Emerald Lake $\bar{x}$ age $=140 \pm 11$ or ca. 1854) indicates that the majority of spruce in both stands regenerated (or more likely released) shortly after the settlement-era (Table 2). For instance, around 1880 the spruce:fir ratio at Emerald Lake increases to its highest values in the historical period, suggesting abundant spruce regeneration and/or release. While spruce can regenerate in open environments and grow rapidly, it also has the unique ability to remain in the seedling bank for many centuries (DeRose and Long 2010) awaiting an opportunity (via canopy removal) to accede to the overstory. Topography and the timing and severity of the harvest likely influenced the ability of spruce to regenerate on the site. The loss of topsoil and alterations to the subalpine microclimate from logging and overgrazing may also have inhibited spruce establishment in the short term at some sites on the Wasatch Plateau (Hall 2001; Arno and Hammerly 1984; Klemmedson and Tiedemann 1998).

While Engelmann spruce can dominate a site after a large-scale disturbance that exposes mineral soil, such as 
fire, reoccupation occurs over centennial time-scales (Alexander 1967, Aplet et al. 1988), and was likely a relatively rare condition for pre-settlement spruce-fir forests of the interior WNA (Alexander 1967; Long 1994). Alternatively, gap-phase dynamics - small gaps created by windthrow, endemic insect populations, or avalanches can be responsible for the initiation of new age cohorts (Whipple and Dix 1979; Veblen 1986). These gaps perpetuate spruce-fir compositional dominance, rather than large-scale disturbances, which are infrequent and climate-limited (Veblen et al. 1994; Schoennagel et al. 2005). As a result, the demographics of spruce and fir are in equilibrium owing to abundant fir regeneration but short lifespan, juxtaposed against sparse regeneration of significantly longer-lived spruce. Based on this characterization of natural spruce-fir forests, Schmid and Frye (1977) suggested minor spruce mortality would occur, but a major epidemic would not be possible until $\sim 500$ years into stand development. Preferential harvesting of spruce would also alter the demographic balance of spruce-fir, initially promoting the short-lived fir. Ultimately, as long-lived spruce, released during settlement harvesting, came to dominate, the stand would become increasingly susceptible to a beetle outbreak.

We determined that reconstructions of host-specific biomass $(\mathrm{C} t / \mathrm{ha})$ revealed important information regarding the vulnerability of subalpine ecosystems that supported a high-severity spruce beetle outbreak. Approximately 140 years after settlement, the cumulative effects of high-grade logging and range deterioration likely resulted in simplified forest structure and composition, dominated by mature spruce. For instance, in the decades leading up to the spruce beetle outbreak (i.e. 1950-1985), average spruce biomass at both lakes was greater than at any other period over the last 200 years (Fig. 4). At Blue Lake, between 1800 and 1994, spruce biomass increased from 12 to $45 \mathrm{t} / \mathrm{ha}^{-1}$, while at Emerald Lake spruce biomass increased from 3 to $>30 \mathrm{t} / \mathrm{ha}^{-1}$. Therefore, when climate became advantageous for spruce beetle fecundity in the 1990s (Hebertson and Jenkins 2008), the broad availability of susceptible spruce hosts $(>10 \mathrm{~cm}$ $\mathrm{dbh}$ ) provided increasing beetle populations with widespread, suitable host substrate to facilitate a landscape-scale outbreak.

In response to the $\sim 1990$ s outbreak, living spruce biomass was drastically reduced, decreasing by $84 \%$ and $86 \%$ at Blue Lake and Emerald Lake, respectively. The outbreak is conspicuous in the vegetation reconstructions as precipitous reductions in both the average spruce/fir pollen ratio (which reflects compositional dominance by spruce) and the reconstructed spruce biomass (Fig. 5). For example, at Blue Lake the spruce/fir ratio dropped from 0.5 to -0.5 and from 0.4 to -0.75 at Emerald Lake in less than a decade. Morris et al. (2013c) demonstrated using a generalized linear mixed model, reductions in the spruce to fir pollen ration is a robust response variable $(p<0.001)$ to spruce beetle outbreaks, shifting by a factor of 2:1 between pre-outbreak (1950 and 1985) and outbreak periods (1985 to 2005).

While detecting the occurrence or severity of past bark beetle events in lake sediments may be challenging given the short temporal duration of outbreak events relative to the typical resolution of sedimentary records (Morris and Brunelle 2012), compositionally related metrics, such as host biomass, can help corroborate modern records (e.g. Dymerski et al. 2001), and help interpret longer records (this study). The biomass transfer function we used in our analysis (Seppä et al. 2009) provides a method to detect past bark beetle outbreaks by first screening for the probability of beetle disturbances based on host abundance. The method can also help in the interpretation of other proxy indicators of past outbreaks, such as shifts in host/non-host ratio, non-pollen palynomorphs of beetle obligates (e.g., blue stain fungi), and preserved beetle remains found in sediments (Brunelle et al. 2008). For example, a number of paleoecological studies of bark beetles have focused on detecting insect disturbances in a similar fashion as wildfire events, by identifying a residual product of the disturbance event in the sedimentary record such as charcoal (e.g. Whitlock and Larsen 2001). However, screening sediments for beetle remains has not proven to be a reliable approach for detecting insect outbreaks because even epidemic populations of bark beetles do not generally leave behind diagnostic remains (Morris et al. 2015). Where diagnostic remains are lacking, biomass transfer functions offer another line of evidence to aide in reconstructing past outbreaks with greater certainty.

\section{Conclusions}

High elevations of the Wasatch Plateau have been dominated by Engelmann spruce forests for the last $\sim 10,500$ years, with subalpine fir becoming more prominent 6000 years ago. This landscape has experienced a dynamic fire regime, where burning events are more frequent and of higher magnitude during the last 3000 years. Despite this shift towards a more intense fire regime, we observed little evidence for species turnover likely due to the improbability of species encroachment from the surrounding expanse of sagebrush steppe. Our evidence, considered alongside other sites in the region, show that high elevation Engelmann spruce ecosystems are resilient to a broad range of climate and disturbance regimes (fire and beetle outbreaks).

The Emerald Lake and Blue Lake records suggest that anthropogenic ecosystem modification from extensive logging during the mid-1800s resulted in historically 
unprecedented forest structure and composition. The legacy of this logging event promoted landscape-level susceptibility to a severe spruce beetle outbreak. Our data suggest that the simplified stand structure and composition found in the late 20th century on the Wasatch Plateau were relatively high in a longer-term context, resulting in a landscape particularly susceptible to bark beetles. Homogeneous coniferous forests are prevalent elsewhere in WNA because the region was settled relatively synchronously and resource exploitation occurred in a similar manner. We speculate that anthropogenic landscape modification through logging could serve as a forest composition simplifying mechanism that would provide suitable, even-aged hosts in landscapes where other native beetles occurring in WNA, such as D. pseudotsugae (Douglas-fir beetle) and D. ponderosae (mountain pine beetle). While climatemediated outbreaks are the ultimate driver of outbreaks, perhaps tree mortality would be less severe in the absence of historic logging events that simplified stand structure and composition.

\section{Competing interests}

The authors declare that they have no competing interests.

\section{Authors' contributions}

JLM conceived and carried out the study and performed field and laboratory analysis. JLM and RJD performed data analysis and drafted the manuscript. $A B$ coordinated field work and contributed to drafting of the manuscript. All authors read and approved the final version.

\section{Acknowledgements}

We are grateful to Diane Cote and Steve Munson for providing stand inventory data from the Manti-LaSal National Forest used in our analysis. We thank Arttu Paarlahti for assistance with data visualization. This paper was prepared in part by an employee of the US Forest Service as part of official duty and is therefore in the public domain.

\section{Author details}

'Department of Forest, Rangeland, and Fire Sciences, College of Natural Resources, University of Idaho, Moscow, ID 83844, USA. ${ }^{2}$ USDA Forest Service, Forest Inventory Analysis, Rocky Mountain Research Station, Ogden, UT 84401, USA. ${ }^{3}$ Department of Geography, University of Utah, Salt Lake City, UT 84112, USA.

Received: 15 June 2015 Accepted: 17 December 2015

Published online: 24 December 2015

\section{References}

Alexander RR (1967) Site indexes for Engelmann spruce. USDA Forest Service Report RM-32: 7 pp.

Anderson L (2011) Holocene record of precipitation seasonality from lake calcite $\delta^{18} \mathrm{O}$ in the central Rocky Mountains, United States. Geology 39:211-4

Anderson RS (1993) A 35000 year vegetation and climate history from Potato Lake, Mogollon Rim, Arizona. Quaternary Res 40:351-9

Anderson RS, Hasbargen J, Koehler PA, Feiler EJ (1999) Late Wisconsin and Holocene subalpine forests of the Markagunt Plateau of Utah, southwestern Colorado Plateau, USA. Arct Antarct Alp Res 31:366-78

Anderson RS, Smith SJ, Lynch AM, Geils BW (2010) The pollen record of a 20th century spruce beetle (Dendroctonus rufipennis) outbreak in a Colorado subalpine forest, USA. For Ecol Manag 260:448-55

Aplet GH, Laven RD, Smith FW (1988) Patterns of community dynamics in Colorado Engelmann spruce-subalpine fir forests. Ecology 69:312-9

Appleby PG, Oldfield F, Thompson R, Huttunen P, Tolonen K. (1979) ${ }^{210} \mathrm{~Pb}$ dating of annually laminated lake sediments from Finland. Nature 280:53-55
Arno SF, Hammerly RP (1984) Timberline: Mountain and Arctic Forest Frontiers. The Mountaineers, Seattle, WA

Bentz BJ et al (2010) Climate change and bark beetles of the western United States and Canada: direct and indirect effects. Bioscience 60:602-13

Blaauw M (2010) Methods and code for 'classical'age-modelling of radiocarbon sequences. Quat Geochron 5:512-8

Blanchette RA (1982) Decay and canker formation by Phellinus pini in white and balsam fir. Can J Forest Res 12:538-44

Brunelle A, Rehfeldt GE, Bentz B, Munson AS (2008) Holocene records of Dendroctonus bark beetles in high elevation pine forests of Idaho and Montana, USA. For Ecol Manag 255:836-46

Calder WJ, Parker D, Stopka CJ, Jiménez-Moreno G, Shuman BN (2015) Medieval warming initiated exceptionally large wildfire outbreaks in the Rocky Mountains. Proc Natl Acad Sci 112:13261-6

Carter VA, Brunelle A, Minckley TA, Dennison PE, Power MJ (2013) Regionalization of fire regimes in the Central Rocky Mountains, USA. Quat Res 80:406-16

Clark JS (1988) Particle motion and the theory of charcoal analysis: source area, transport, deposition, and sampling. Quat Res 30:67-80

Critchfield WB, Little EL (1966) Geographic distribution of the pines of the world. US Department of Agriculture, Forest Service Publication 991.

Dawson TP, Jackson ST, House JI, Prentice IC, Mace GM (2011) Beyond predictions: biodiversity conservation in a changing climate. Science 332:53-8

DeRose RJ, Long JN (2010) Regeneration response and seedling bank dynamics on a Dendroctonus rufipennis-killed Picea engelmannii landscape. J Veg Sci 21:377-87

Dymerski AD, Anhold JA, Munson AS (2001) Spruce beetle (Dendroctonus rufipennis) outbreak in Engelmann spruce (Picea engelmannii) in central Utah, 1986-1998. West N Am Nat 61:19-24

Enache MD, Cumming BF (2007) Charcoal morphotypes in lake sediments from British Columbia (Canada): an assessment of their utility for the reconstruction of past fire and precipitation. J Paleolimn 38:347-63

Ellison L (1954) Subalpine vegetation of the Wasatch Plateau, Utah. Ecol Monogr 24:89-184

Fægri K, Kaland PE, Kryzywinski K (1989) Textbook of pollen analysis, 4th edn. John Wiley, Chichester, UK

Flannigan MD, Krawchuk MA, de Groot WJ, Wotton BM, Gowman LM (2009) Implications of changing climate for global wildland fire. Int J Wildland Fire 18:483-507

Gardner JJ, Whitlock C (2001) Charcoal accumulation following a recent fire in the Cascade Range, northwestern USA, and its relevance for fire-history studies. The Holocene 11:541-9

Gavin DG, Hu FS, Lertzman K, Corbett P (2006) Weak climatic control of standscale fire history during the late Holocene. Ecology 87:1722-32

Giesecke T, Fontana SL, Knaap WO, Pardoe HS, Pidek IA (2010) From early pollen trapping experiments to the Pollen Monitoring Programme. Veg Hist Archaeobot 19:247-58

Gill RA (2007) Influence of 90 years of protection from grazing on plant and soil processes in the subalpine of the Wasatch Plateau, USA. Rangeland Ecol Manag 60:88-98

Hall M (2001) Repairing mountains: restoration, ecology, and wilderness in twentieth-century Utah. Environ Hist 6:584-610

Higuera PE, Brubaker LB, Anderson PM, Hu FS, Brown TA (2009) Vegetation mediated the impacts of postglacial climate change on fire regimes in the south-central Brooks Range, Alaska. Ecol Monog 79:201-19

Higuera PE, Gavin DG, Bartlein PJ, Hallett DJ (2010) Peak detection in sedimentcharcoal records: impacts of alternative data analysis methods on fire-history interpretations. Int J Wildland Fire 19:996-1014

Jeffers ES, Nogué S, Willis KJ (2015) The role of palaeoecological records in assessing ecosystem services. Quaternary Sci Rev 112:17-32

Hebertson EG, Jenkins MJ (2008) Climate factors associated with historic spruce beetle (Coleoptera: Curculionidae) outbreaks in Utah and Colorado. Environ Entomol 37:281-92

Kapp RO, Davis OK, King JE (2000) Pollen and Spores, 2nd edn. American Association of Stratigraphic Palynologists, New York

Klemmedson JO, Tiedemann AR (1998) Soil-vegetation relations of recovering subalpine range of the Wasatch Plateau. West N Am Nat 58:352-62

Long JN (1994) The middle and southern Rocky Mountain Region. Regional Silviculture of the United States. John Wiley \& Sons, New York, NY

Minckley TA, Shriver RK, Shuman BN (2012) Resilience and regime change in a southern Rocky Mountain ecosystem during the past 17000 years. Ecol Monog 82:49-68 
Mock CJ (1996) Climatic controls and spatial variations of precipitation in the western United States. J Climate 9:1111-25

Morris JL, Brunelle AR, Munson AS (2010) Pollen evidence of historical forest disturbance on the Wasatch Plateau, Utah. West N Am Nat 70:175-88

Morris JL, Brunelle AR (2012) Pollen accumulation in lake sediments during historic spruce beetle disturbances in subalpine forests of southern Utah, USA. The Holocene 22:961-74

Morris JL, Brunelle A, DeRose RJ, Seppä H, Power MJ, Carter V, Bares R (2013) Using fire regimes to delineate zones in a high-resolution lake sediment record from the western United States. Quat Res 79:24-36

Morris JL, Brunelle A, Munson AS, Spencer J, Power MJ (2013b) Holocene Vegetation and Fire Reconstructions from the Aquarius Plateau, Utah, USA. Quat Int 310:111-23

Morris JL, le Roux PC, Macharia AN, Brunelle A, Hebertson EG, Lundeen ZJ (2013C) Organic, elemental, and geochemical contributions to lake sediment deposits during severe spruce beetle (Dendroctonus rufipennis) disturbances. For Ecol Manag 289:78-89

Morris JL, Mustaphi CJC, Carter VA, Watt J, Derr K, Pisaric, MFJ, Anderson RS, Brunelle AR (2015). Do bark beetle remains in lake sediments correspond to severe outbreaks? A review of published and ongoing research. Quaternary Int 387:72-86.

Moy CM, Seltzer GO, Rodbell DT, Anderson DM (2002) Variability of El Niño/ Southern Oscillation activity at millennial timescales during the Holocene epoch. Nature 420:162-5

Notaro M, Mauss A, Williams JW (2012) Projected vegetation changes for the American Southwest: combined dynamic modeling and bioclimaticenvelope approach. Ecol Appl 22:1365-88

O'Connor CD, Falk DA, Lynch AM, Swetnam TW (2014) Fire severity, size, and climate associations diverge from historical precedent along an ecological gradient in the Pinaleño Mountains, Arizona, USA. For Ecol Manag 329:264-78

Odion DC, Moritz MA, DellaSala DA (2010) Alternative community states maintained by fire in the Klamath Mountains, USA. J Ecol 98:96-105

Peet RK (1981) Forest vegetation of the Colorado front range. Vegetatio 45:3-75

Raffa KF, Aukema BH, Bentz BJ, Carroll AL, Hicke JA, Turner MG, Romme WH (2008) Cross-scale drivers of natural disturbances prone to anthropogenic amplification: the dynamics of bark beetle eruptions. Bioscience 58:501-17

Rehfeldt GE, Crookston NL, Warwell MV, Evans JS (2006) Empirical analyses of plant-climate relationships for the western United States. Int J Plant Sci 167: 1123-50

Reinemann SA, Porinchu DF, Bloom AM, Mark BG, Box JE (2009) A multi-proxy paleolimnological reconstruction of Holocene climate conditions in the Great Basin, United States. Quaternary Res 72:347-358.

Reimer PJ, Bard E, Bayliss A, Beck JW, Blackwell PG, Bronk Ramsey, Buck CE, Cheng $\mathrm{H}$, Edwards L, Friedrich M, Grootes PM, Guilderson TP, Haflidason $H_{\text {, }}$ Hajdas I, Hatté C, Heaton TJ, Hoffmann DL, Hogg AG, Hughen KA, Kaiser KF, Kromer B, Manning SW, Niu M, Reimer RW, Richards DA, Scott EM, Southon JR, Staff RA, Turney CSM, van der Plicht J. (2013) IntCal13 and Marine13 radiocarbon age calibration curves $0-50,000$ years cal BP. Radiocarbon 55: 1869-1887.

Savage M, Mast JN (2005) How resilient are southwestern ponderosa pine forests after crown fires? Can J For Res 35:967-77

Schmid JM, Frye RH (1977) Spruce beetle in the Rockies. USDA Forest Service General Technical Report RM-49: 38 pp.

Schoennagel T, Veblen TT, Romme WH, Sibold JS, Cook ER (2005) ENSO and PDO variability affect drought-induced fire occurrence in Rocky Mountain subalpine forests. Ecol Appl 15:2000-14

Seppä H, Alenius T, Muukonen P, Miller PA, Ojala AEK (2009) Calibrated pollen accumulation rates as a basis for quantitative tree biomass reconstructions. The Holocene 19:209-20

Ter-Mikaelian MT, Korzukhin MD (1997) Biomass equations for sixty-five North American tree species. For Ecol Manag 97:1-24

Turner MG (2010) Disturbance and landscape dynamics in a changing world. Ecology 91:2833-49

Veblen TT (1986) Age and size structure of subalpine forests in the Colorado Front Range. Bull Torrey Bot Club 113:225-40

Veblen TT, Hadley KS, Nel EM, Kitzberger T, Reid M, Villalba R (1994) Disturbance regime and disturbance interactions in a Rocky Mountain subalpine forest. J Ecol 82:125-35

Weng C, Jackson ST (1999) Late Glacial and Holocene vegetation history and paleoclimate of the Kaibab Plateau, Arizona. Palaeogeog, Palaeoclim, Palaeoecol 153:179-201
Westerling AL, Hidalgo HG, Cayan DR, Swetnam TW (2006) Warming and earlier spring increase western US forest wildfire activity. Science 313:940-3

Whipple SA, Dix RL (1979) Age structure and successional dynamics of a Colorado subalpine forest. Am Midl Nat 101:142-58

Whitlock C, Millspaugh SH (1996) Testing the assumptions of fire-history studies: an examination of modern charcoal accumulation in Yellowstone National Park, USA. The Holocene 6:7-15

Whitlock C, Larsen CPS (2001) Charcoal as a fire proxy. In Tracking environmental change using lake sediments. Springer, The Netherlands, pp 75-97

Whitlock C, Higuera PE, McWethy DB, Briles CE (2010) Paleoecological perspectives on fire ecology: revisiting the fire-regime concept. Open Ecol J 3:6-23

Willis KJ, Birks HJB (2006) What is natural? The need for a long-term perspective in biodiversity conservation. Science 314:1261-5

Willis KJ, Bailey RM, Bhagwat SA, Birks HJB (2010) Biodiversity baselines, thresholds and resilience: testing predictions and assumptions using palaeoecological data. Trends Ecol Evol 25:583-91

Wise EK (2010) Spatiotemporal variability of the precipitation dipole transition zone in the western United States. Geophys Res Lett 37: 10.1029/ 2009GL042193.

\section{Submit your manuscript to a SpringerOpen ${ }^{\circ}$ journal and benefit from:}

- Convenient online submission

- Rigorous peer review

- Immediate publication on acceptance

- Open access: articles freely available online

- High visibility within the field

- Retaining the copyright to your article

Submit your next manuscript at $>$ springeropen.com 